\title{
Erratum: Drug Discovery Approaches to Target Wnt Signaling in
} Cancer Stem Cells

\section{Joshua C. Curtin and Matthew V. Lorenzi}

${ }^{1}$ Oncology Drug Discovery, Research and Development, Bristol-Myers Squibb, Princeton, NJ, USA

Published: October 05, 2018

Copyright: Curtin et al. This is an open-access article distributed under the terms of the Creative Commons Attribution License 3.0 (CC BY 3.0), which permits unrestricted use, distribution, and reproduction in any medium, provided the original author and source are credited.

This article has been corrected: During production, the page numbers for this article were listed incorrectly. The page numbers have now been adjusted to show the proper pagination.

Original article: Oncotarget. 2010; 1:563-577. https://doi.org/10.18632/oncotarget.191 